Journal of Environmental Sciences (JES)

Institute of Environmental Studies and Research, Ain Shams University

Ahmed, Ayman. et al.

\title{
SOME MORPHOMETRIC RELATIONSHIPS OF SANDBIRD OCTOPUS, AMPHIOCTOPUS AEGINA (GRAY, 1849) (CEPHALOPODA: OCTOPODIDAE) FROM THE SUEZ GULF, RED SEA
}

\author{
Ayman S. A. Ahmed ${ }^{(1)}$; Mohamed F. Osman (2); Magdy T. Khalil ${ }^{(3)}$ \\ And Azza A. El-Ganainy ${ }^{(1)}$ \\ 1) National Institute of Oceanography and Fisheries.2) Faculty of Agriculture \\ , Ain Shams University.3) Faculty of Science, Ain Shams University.
}

\begin{abstract}
Octopus is an important resource for the fisheries sector and has commercial value. For this reason, maintenance and conservation is requisite to preserve and keeping its survival. So, some morphometric relationships of Amphioctopus aegina was studied at the Gulf of Suez - Northern Red Sea. The results showed that the length-weight relationship of dorsal mantle length (DML) with total weight (TW) of A. aegina is negative allometric and obtained by the formula $\mathrm{Y}=0.5198 \mathrm{X}^{2.6696}$ with the correlation coefficient of $r^{2}=0.8998$ for males and $Y=0.8065 X^{2.4042}$ with the correlation coefficient of $r^{2}=0.9319$ for females. The results indicated that $90 \%$ or more of weight gain occurs due to the old growth of the octopus body, while $10 \%$ or less of weight gain is affected by other factors such as environmental conditions and age factors. The length-length relationships of DML with the different body measurements of $A$. aegina showed a negative allometric $(b<1)$. While, the relations of DML with long arm length (LAL), total length (TL) and short arm length (SAL) were positive allometric growth $(b>1)$ for males and females and the correlation coefficient $\left(\mathrm{r}^{2}\right)$ showed a good fitted data for all relationships.
\end{abstract}

Keywords: Amphioctopus aegina; Morphometric measurements; lengthweight relationship; length-length relationships; Suez Gulf. 
Journal of Environmental Sciences (JES)

Institute of Environmental Studies and Research, Ain Shams University

Ahmed, Ayman. et al.

\section{INTRODUCTION}

The Gulf of Suez (Fig. 1) considered as one of the major sources of fish production in the Egyptian sector of the Red Sea. Its importance as fish resource can be attributed to the shallowness and sandy bottom, which make it suitable for trawling. It is characterized by the presence of a great diversity of highly economic fish and invertebrate species (Sanders \& Morgan, 1989). The exploitation of fisheries resources in the Gulf of Suez has greatly contributed to the development of the fisheries and national economy; however, the status of fisheries resources and the ecosystem structure in the Gulf have substantially changed. The fisheries resources in the Gulf of Suez are depicted and the ecosystem had large changes, switching from large-size and high value demersal fisheries dominated ecosystem to an ecosystem dominated by small-size and low value pelagic fisheries (GAFRD, 2018).

Recent studies have shown that coastal and shelf cephalopod populations have increased globally over the last six decades. Although cephalopod landings are dominated by the squid fishery, which represents nearly $80 \%$ of the worldwide cephalopod catches, octopuses and cuttlefishes represent $\sim 10 \%$ each. Total reported global production of octopuses over the past three decades indicates a relatively steady increase in catch, almost doubling from $179,042 \mathrm{t}$ in 1980 to $355,239 \mathrm{t}$ in 2014 (Sauer et al., 2019). Octopuses are relatively abundant in the trawl landings of the Gulf of Suez; they were discarded species till 1990's (El-Ganainy et al., 2005), but currently they have 
Journal of Environmental Sciences (JES)

Institute of Environmental Studies and Research, Ain Shams University

Ahmed, Ayman. et al.

a relatively high occurrence and commercial importance in the trawl landings, representing about $0.07 \%$ of the total trawl catch (GAFRD, 2018).

In the Gulf of Suez it is found that the octopus catch was composed of four species: Amphioctopus aegina, Amphioctopus membranaceus, Octopus cyanea and Macrotritopus defilippi. Among the four species, A. aegina and A. membranaceus were the most dominant and available throughout the year. These species were identified based on FAO species catalogue for fishery purposes (Jereb et al., 2014). In the recent revision on octopods (Norman \& Hochberg, 2005) the genus Octopus was synonymized by genus Amphioctopus.

A number of morphometric studies have been carried out in other parts of the world on various octopus species, showing that both species and sexes can be separated on a morphological basis (Norman \& Hochberg, 2005). Few studies have been done on the morphometric characters of Octopoda in the Egyptian waters (Riad \& Gabr, 2007; Riad, 2008; El-Ganainy \& Riad, 2008; Osman et al., 2014).

The study of the length-length and length-weight relationships of octopus is one of the information that needs to be known and it is important in managing octopus fisheries resources. Richter (2007) mentioned that the measurement of fish weight aims to determine the specific weight and length variations of individual fish or groups of individuals as an indication of obesity, health, productivity and physiological conditions including gonad development. Therefore, this study aims to determine the pattern of growth 
through morphometric relationships of A. aegina in the Gulf of Suez to help in the proper management and sustainability of this species.

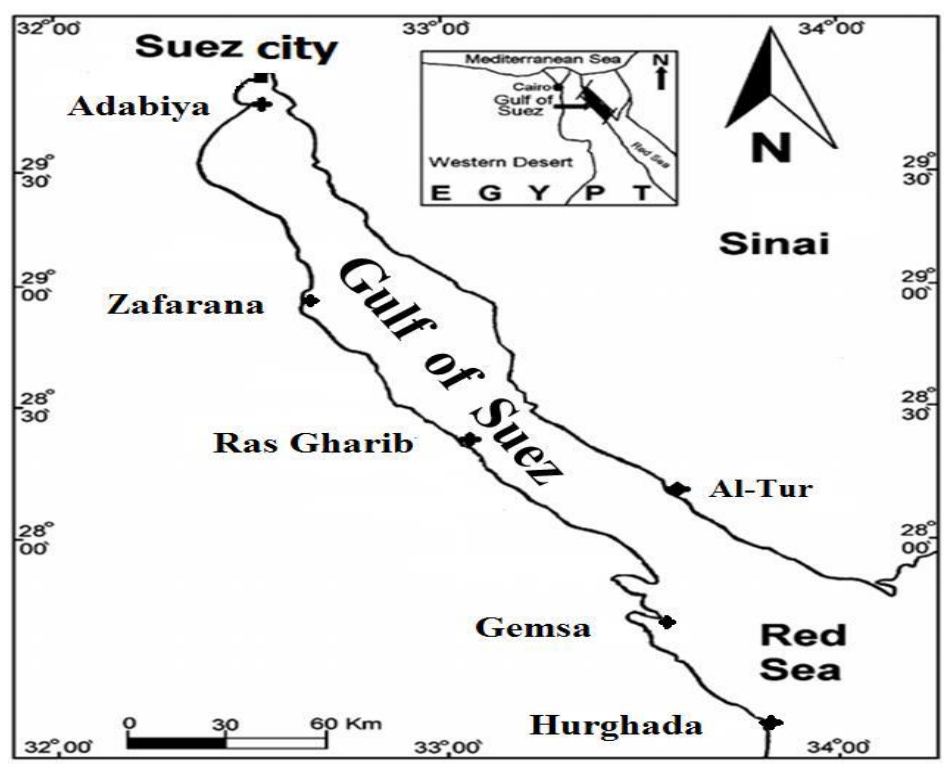

Fig. (1): Map showing Gulf of Suez.

\section{MATERIALS AND METHODS}

This research was carried out for eight months starting from September 2017 to April 2018 fishing season. The total number of A. aegina samples were 450 collected from commercial trawlers at Attaka fishing harbor. Samples were transported to the Fisheries Biology Laboratory of the National Institute of Oceanography and Fisheries, Suez Branch. Individuals were dissected and sorted by sex. A single set of a divider, ruler and an electronic balance were used on all samples, and all measurements were conducted by 
one author to avoid unnecessary variations (All lengths were measured to the nearest $0.1 \mathrm{~cm}$ and total weight to the nearest $0.1 \mathrm{gm}$ ).

Length-weight relationship was carried out between dorsal mantle length (DML) and total weight (TW) for males and females of A. aegina by the growth equation (power regression) according to Bowker (1995):

$$
\mathrm{Y}=\mathrm{a} \mathrm{X}^{\mathrm{b}}
$$

Where, $\mathrm{Y}$ is a weight variable $(\mathrm{gm}), \mathrm{X}$ is the length variable $(\mathrm{cm}), \mathrm{a}$ and $\mathrm{b}$ are constants.

The linear regression equation $(Y=a+b X)$ was used to describe the relation between different body measurements (length-length) as:

1- Mantle width (MW) and dorsal mantle length (DML).

2- Head length (HL) and dorsal mantle length (DML).

3- Head width (HW) and dorsal mantle length (DML).

4- Long arm length (LAL) and dorsal mantle length (DML).

5- Total length (TL) and dorsal mantle length (DML).

6- Short arm length (SAL) and dorsal mantle length (DML).

7- Ventral mantle length (VML) and dorsal mantle length (DML).

8- Funnel length (FL) and dorsal mantle length (DML).

Where, $\mathrm{Y}$ is the dependent variable; $\mathrm{X}$ is the independent variable of the length $(\mathrm{cm})$; $\mathrm{a}$ is a constant (the intercept of the regression line) and $\mathrm{b}$ is the slope regression coefficient that gives the rate at which the variable $\mathrm{Y}$ alter with the variable $X$. 
Journal of Environmental Sciences (JES)

Institute of Environmental Studies and Research, Ain Shams University

Ahmed, Ayman. et al.

When the two variables have the same units of measurement (i.e. lengthlength relationship), value of the exponent $b$ that is greater than unity (1) indicates positive allometric. While value of the exponent $b$ is lesser than unity (1), indicates negative allometric. But value of unity for the exponent $b$ describes an isometric relationship when it equals (1). In case of different units of measurement for the two variables (i.e. length-weight relationship), different criteria for allometric and isometric applied were value of the exponent $b=3$ that corresponds to isometric (Gould, 1966). The growth is allometric if $b \neq 3$ (negative allometric if $b<3$ and positive allometric if $b>3$ ) (Ricker, 1975).

\section{RESULTS AND DISCUSSION}

Morphometric analysis: Some morphometric relationships as: length-length and length-weight relationships were determined for males and females of A. aegina. A length-length and length-weight measurement aims to determine the pattern of growth by using length and weight parameters. It can also describe the growth pattern and the effect of environmental changes on the growth of animal. The number of A. aegina measured during the study was 450 (222 males and 228 females). The results showed linear models for length-length relationships and power models for length-weight relationships.

\section{A- Length-length relationships}

1. Dorsal mantle length - mantle width relationship: A linear relation between dorsal mantle length (DML) and mantle width (MW) showed a 
positive significant relationship $(\mathrm{P}<0.001)$ and were represented by the

following equations:

$\mathrm{MW}=0.7167 \mathrm{DML}+0.357 \& \mathrm{r} 2=0.8779$ (males)

$\mathrm{MW}=0.6698 \mathrm{DML}+0.6669 \& \mathrm{r} 2=0.9089$ (females).

The correlation coefficient $\left(\mathrm{r}^{2}\right)$ showed a good fitted data and the exponent $b$ values indicated a negative allometric (Fig. 2).

2. Dorsal mantle length - head length relationship: A linear regression between dorsal mantle length (DML) and head length (HL) showed a positive significant relationship $(\mathrm{P}<0.001)$ and were represented by the following equations:

$\mathrm{HL}=0.2504 \mathrm{DML}+0.2912 \& \mathrm{r}^{2}=0.8377$ (males).

$\mathrm{HL}=0.1168 \mathrm{DML}+0.7436 \& \mathrm{r}^{2}=0.8776$ (females)

The correlation coefficient $\left(\mathrm{r}^{2}\right)$ showed a good fitted data and the exponent b values indicated a negative allometric growth as shown in Figure (3). 


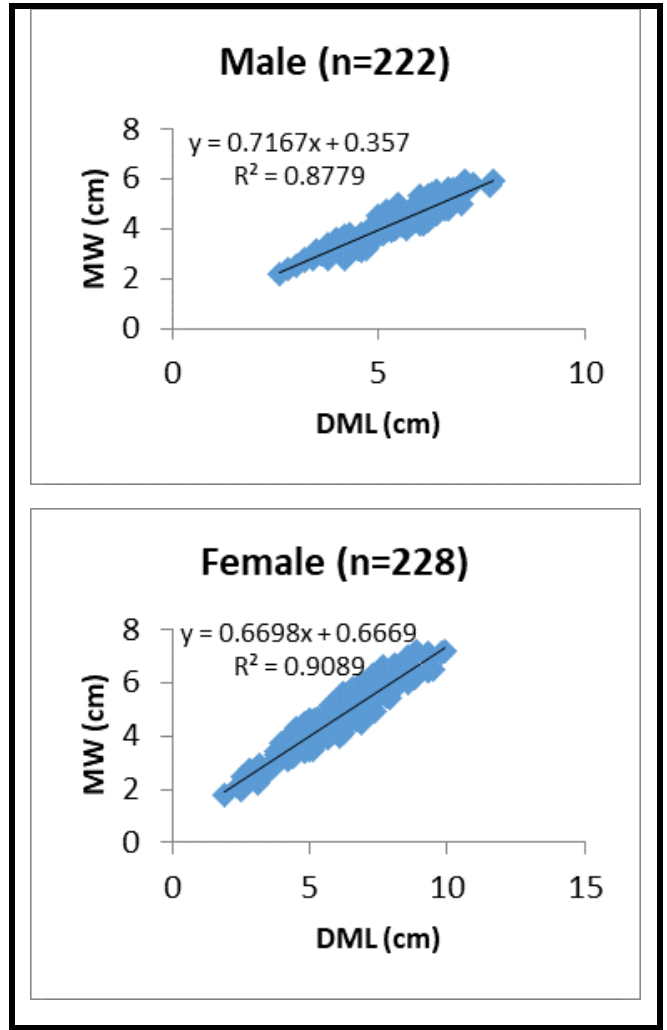

Figure (2): Dorsal mantle length and mantle width relationship for males and females of A. aegina from the Gulf of Suez.

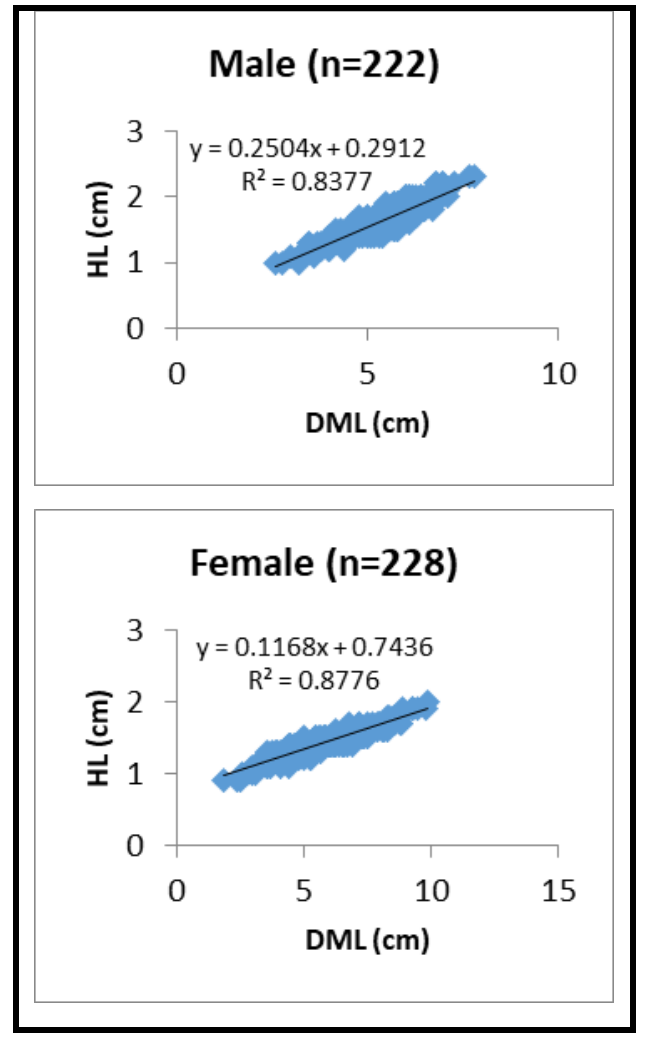

Figure (3): Dorsal mantle length and head length relationship for males and females of A. aegina from the Gulf of Suez.

3. Dorsal mantle length - head width relationship: The relation between dorsal mantle length (DML) and head width (HW) gave a positive significant relationship $(\mathrm{P}<0.001)$. The correlation coefficient $\left(\mathrm{r}^{2}\right)$ showed 
a good fitted data where the exponent $b$ values indicated a negative allometric (Fig. 4) and were represented by the following equations:

$\mathrm{HW}=0.2798 \mathrm{DML}+0.4922 \& \mathrm{r}^{2}=0.8129$ (males).

$\mathrm{HW}=0.1958 \mathrm{DML}+0.9557 \& \mathrm{r}^{2}=0.8797$ (females).

4. Dorsal mantle length - long arm length relationship: A linear relation between dorsal mantle length (DML) and long arm length (LAL) showed a positive significant relationship $(\mathrm{P}<0.001)$ and were represented by the following equations:

$\mathrm{LAL}=3.3333 \mathrm{DML}+0.8236 \& \mathrm{r}^{2}=0.8509$ (males).

$\mathrm{LAL}=3.057 \mathrm{DML}+2.6117 \& \mathrm{r}^{2}=0.8907$ (females).

The exponent $b$ value indicated a positive allometric growth and the correlation coefficient $\left(\mathrm{r}^{2}\right)$ showed a good fitted data as shown in Figure (5). 


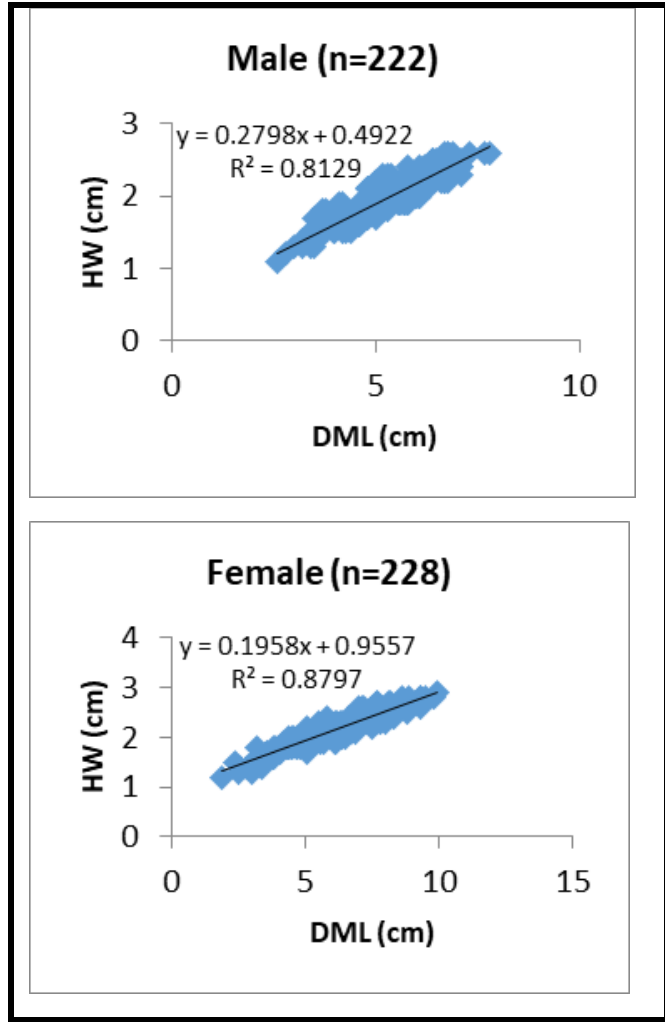

Figure (4): Dorsal mantle length and head width relationship for males and females of A. aegina in the Suez Gulf.

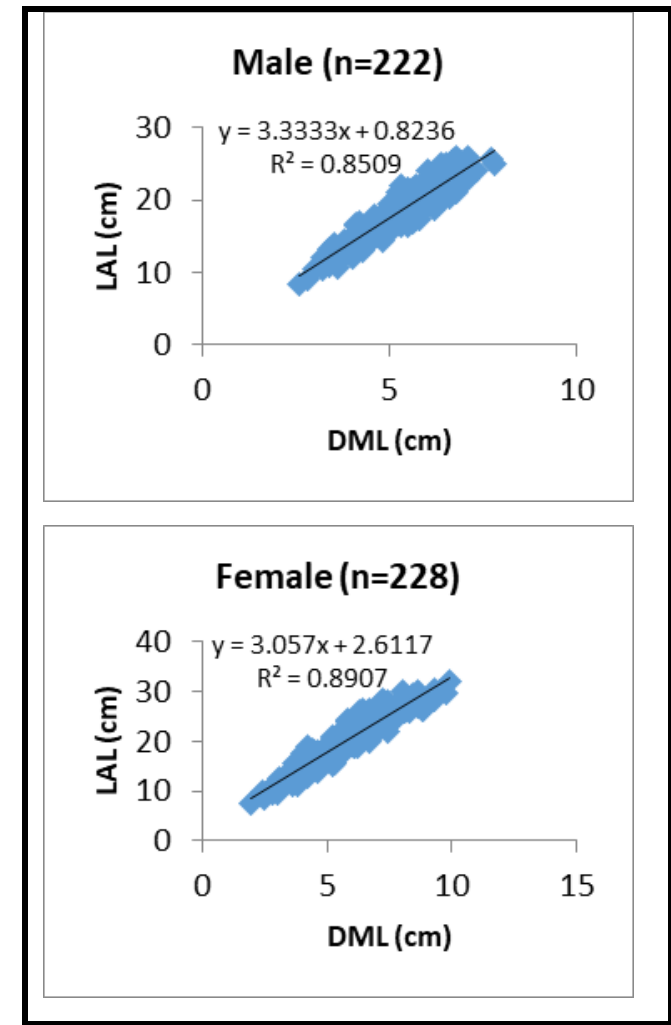

Figure (5): Dorsal mantle length and long arm length relationship of $\mathrm{A}$. aegina from the Gulf of Suez.

5. Dorsal mantle length - total length relationship: The correlation coefficient $\left(r^{2}\right)$ showed a good fitted data and the exponent $b$ values indicated a positive allometric on establishing a relationship between dorsal mantle length (DML) and total length (TL). It was positive and significant relationship $(\mathrm{P}<0.001)$ as shown in Figure (6) and were represented by the following equations: 
$\mathrm{TL}=4.729 \mathrm{DML}+1.6453 \& \mathrm{r}^{2}=0.8494$ (males).

$\mathrm{TL}=4.1173 \mathrm{DML}+4.9702 \& \mathrm{r}^{2}=0.9003$ (females).

6. Dorsal mantle length - short arm length relationship: The correlation coefficient showed a good fitted data and the exponent $b$ values indicated $a$ positive allometric on establishing a relationship between dorsal mantle length (DML) and short arm length (SAL). It was positive and significant relationship $(\mathrm{P}<0.001)$ as shown in Figure $(7)$ and were represented by the following equations:

$\mathrm{SAL}=1.5833 \mathrm{DML}+3.7875 \& \mathrm{r}^{2}=0.824$ (males).

$\mathrm{SAL}=2.6055 \mathrm{DML}+0.3297 \& \mathrm{r}^{2}=0.889$ (females). 


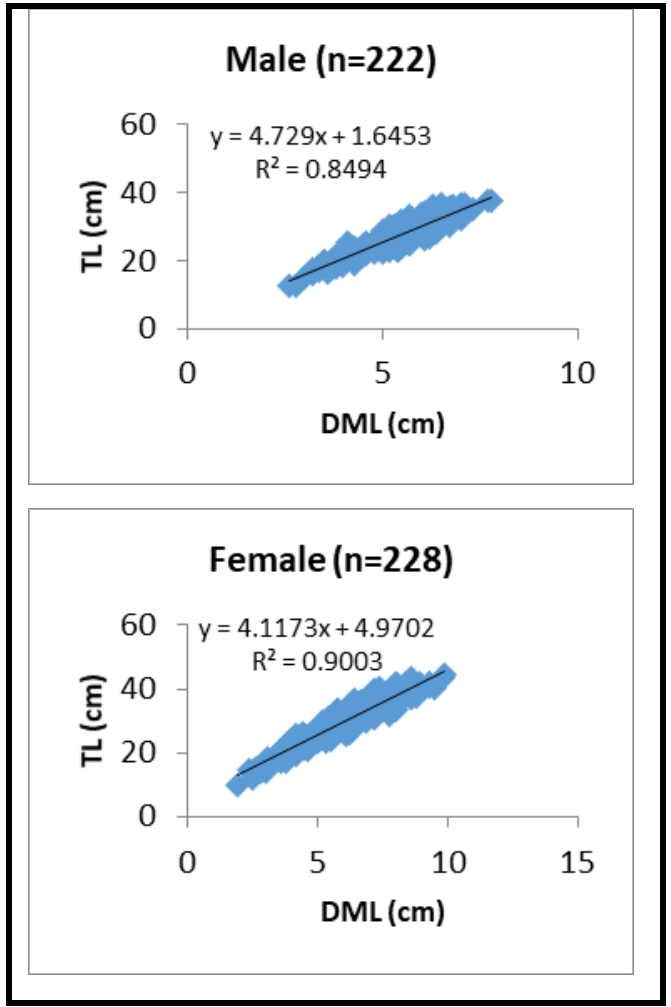

Figure(6): Dorsal mantle length and total length relationship for males and females of A. aegina in the Suez Gulf.

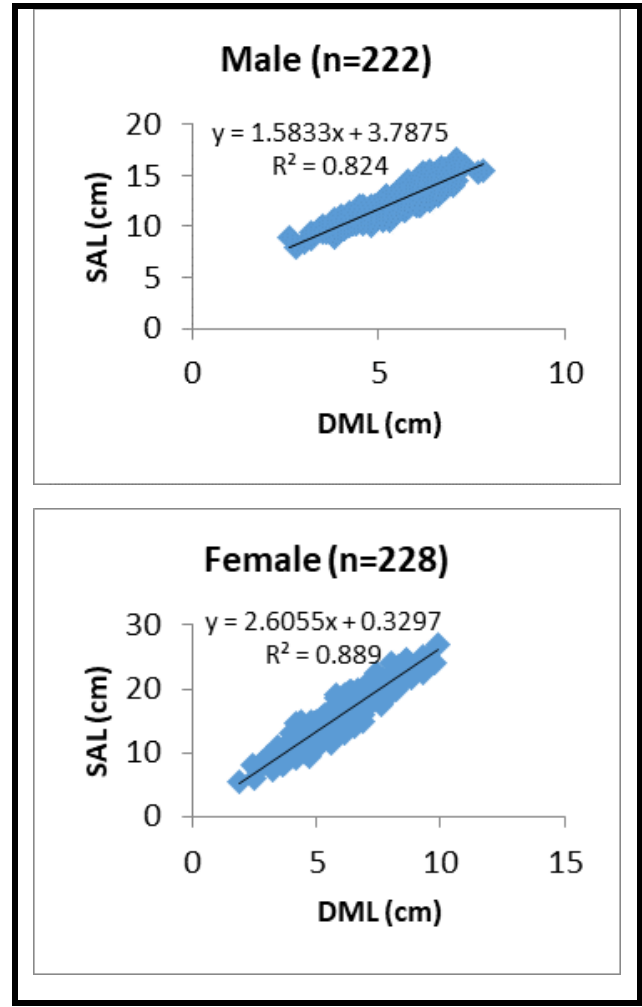

Figure(7): Dorsal mantle length and short arm length relationship of $A$. aegina from the Gulf of Suez.

7. Dorsal mantle length - ventral mantle length relationship: The relation between dorsal mantle length (DML) and ventral mantle length (VML) was highly correlated and a positive significant relationship was obtained $(\mathrm{P}<0.001)$. The exponent $\mathrm{b}$ values indicated a negative allometric and the 
correlation coefficient showed a good fitted data (Fig. 8) and were represented by the following equations:

$\mathrm{VML}=0.8113 \mathrm{DML}+0.0061 \& \mathrm{r}^{2}=0.8923$ (males).

$\mathrm{VML}=0.8299 \mathrm{DML}-0.1157 \& \mathrm{r}^{2}=0.9554$ (females).

8. Dorsal mantle length - funnel length relationship: A linear relation between dorsal mantle length (DML) and funnel length (FL) showed a positive significant relationship $(\mathrm{P}<0.001)$ and were represented by the following equations:

$\mathrm{FL}=0.4499 \mathrm{DML}-0.0282 \& \mathrm{r}^{2}=0.8643$ (males).

$\mathrm{FL}=0.3821 \mathrm{DML}+0.3821 \& \mathrm{r}^{2}=0.9365$ (females).

The correlation coefficient showed a good fitted data and the exponent $b$ values indicated a negative allometric as shown in Figure (9). 


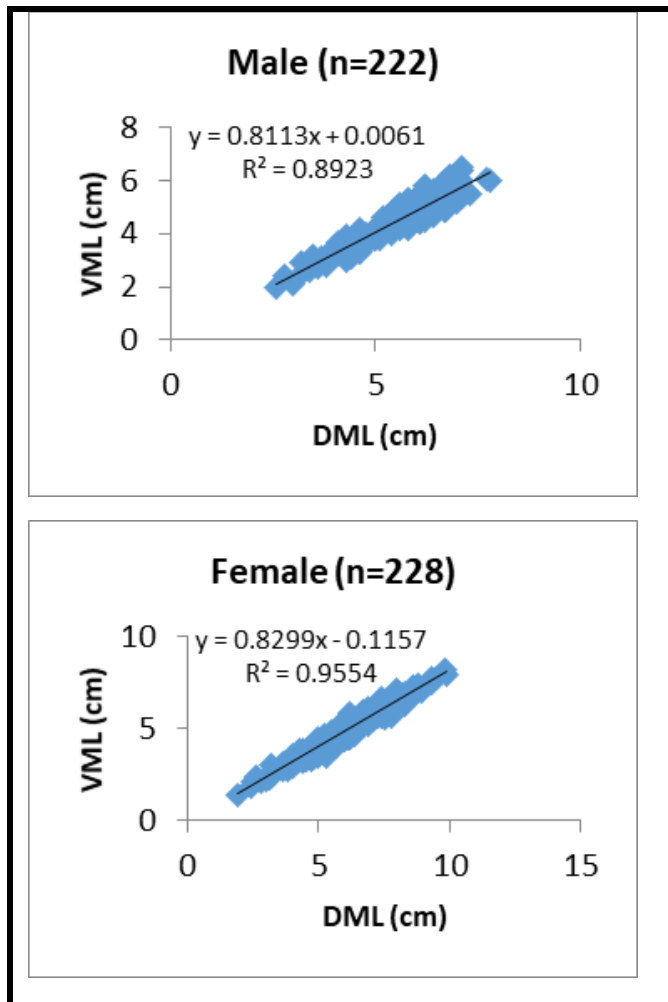

Figure (8): Dorsal mantle length and ventral mantle length relationship for A. aegina from the Gulf of Suez.

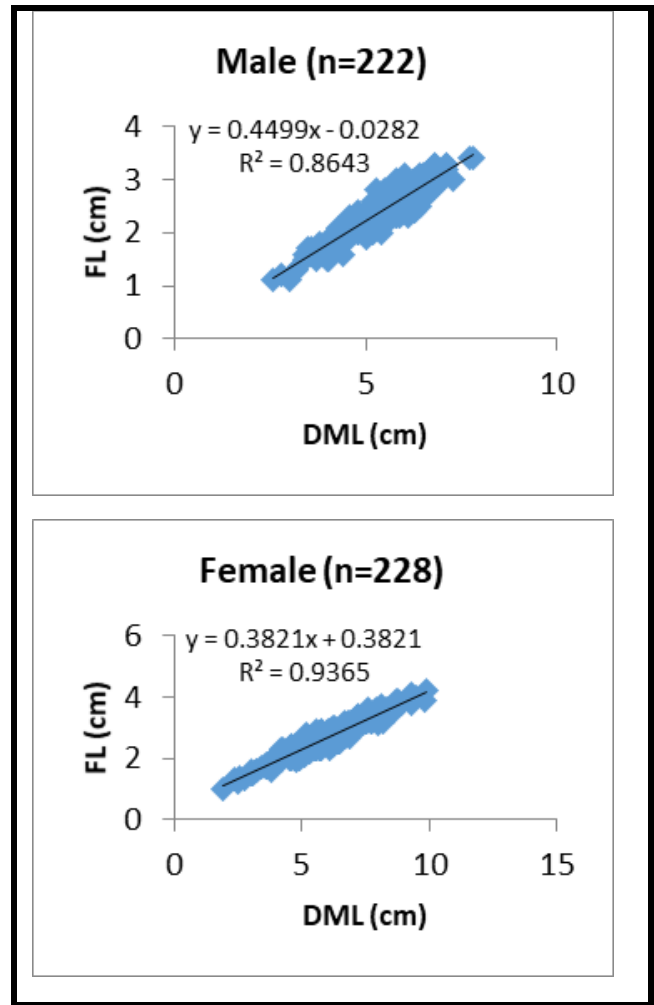

Figure (9): Dorsal mantle length and funnel length relationship for A. aegina in the Gulf of Suez.

B- Length-weight relationship: Dorsal mantle length, total weight relationship:

A power regression between dorsal mantle length (DML) and total weight (TW) was highly correlated and a positive significant relationship was obtained $(\mathrm{P}<0.001)$ and were represented by the following equations: 
TW $=0.5198$ DML2.6696 \& r2 $=0.8998$ (males).

TW $=0.8065$ DML2.4042 \& r2 $=0.9319$ (females).

The correlation coefficient ( $\mathrm{r} 2$ ) showed a good fitted data and the exponent $\mathrm{b}$ values indicated a negative allometric (Fig. 10).
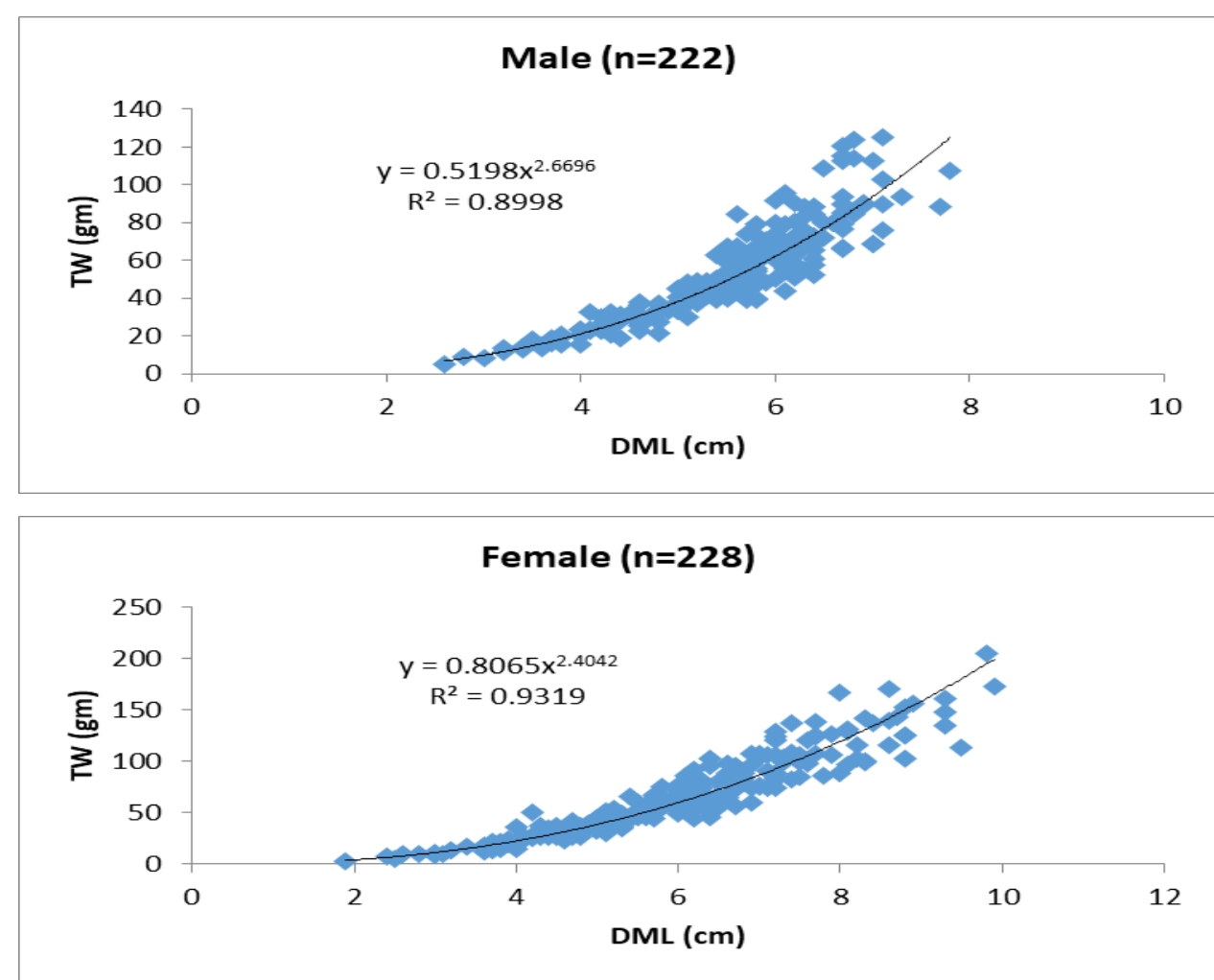

Figure (10): Dorsal mantle length and total weight relationship for males and females of A. aegina from the Gulf of Suez during 2017/2018.

The pattern of octopus growth can be determined from the constant value b. If $b>3$, then the relationship is positive allometric, where weight gain is more than the increase in length. Conversely, if $b<3$, the relationship formed 
Journal of Environmental Sciences (JES)

Institute of Environmental Studies and Research, Ain Shams University

Ahmed, Ayman. et al.

is negative allometric where the length increase is more dominant than the weight gain. While, $b=3$, the growth is isometric (length increase is proportional to weight gain), (Effendie, 2002).

In the present study, the correlation value $\left(r^{2}\right)$, which is close to 1 , indicating a close enough and good relationship between growth of weight and octopus length. The $\mathrm{b}$ values mostly were less than 1 in length-length relationships and totally less than 3 in length-weight relationships (all morphometric relationships of A. aegina showed a negative allometric except that of DML with LAL, TL and SAL were positive allometric growth for males and females). These results are more or less similar with (Osman et al., 2014), who studied the length weight relationship of Octopus aegina in the Suez Canal, Gulf of Suez and Mediterranean Sea. In the Suez Canal, octopuses grow isometrically as b values are equal to 3 for males, females and combined sexes. In the Gulf of Suez, octopuses seem to have positive allometric growth as b values is significantly higher than 3 for both sexes and combined sexes. In the Mediterranean Sea, octopuses grow in negative allometric manner as $b$ values are significantly lower than 3 for both sexes and combined sexes. El-Ganainy \& Riad (2008) investigated some morphometric relationships for each sex separately by fitting regressions to total length on total weight, mantle length on total weight and total length on mantle length of Octopus defilippi in the Gulf of Suez and they found that the growth in weight was allometrically negative in all three cases for males and females. 
Journal of Environmental Sciences (JES)

Institute of Environmental Studies and Research, Ain Shams University

Ahmed, Ayman. et al.

Also, these findings were in agreement with Yedukondala \& Mohana (2013), who indicated that the length-weight relationship of Octopus membranaceus in Visakhapatnam, east coast of India was negative allometric growth and the growth coefficient (b) was 2.1331, 2.6836 and 2.3724 for males, females and sex combined, respectively. Marzuki et al. (2018) reported the growth patterns of Octopus (Octopus spp.) from North Lombok, Indonesia, with b value of 2.1279. According to Effendie (1997), the lengthterm relationships suggest that relative growth means the potential to change according to time. If there is a variation in the environment and food availability this value will also changed. Further clarified that there are several factors that affect growth, including internal factors and external factors including the amount and size of food available, temperature, dissolved oxygen, water quality parameters, age and gonads maturation. Suruwaky \& Gunaisah (2013) mentioned that, the low value of $b(b<3)$ can be caused by over-exploitation through fishing catches that affect the lengthweight. In addition, the growth is influenced by biological factors both gonad growth and sex, and the environment in providing sufficient food and water conditions (Effendie, 1997; Rosli \& Isa, 2012).

The allometry coefficient (b) differs according to the different hydrological and sedimentological features in various geographical areas (Gaspar et al., 2002). Besides that, seasonal variations can also influence the growth. According to Welcomme (2001) growth will generally increase during the rainy season (water rises) and will slow down in the dry season. 
This is because seasonal differences will cause changes in food availability, temperature, food activity and spawning activities.

In conclusion, the results of the present study concerning the relationships between dorsal mantle length and all octopus body measurements maybe an indication of specific environmental factors in the Gulf of Suez, where the environmental conditions, such as: water temperature, salinity, $\mathrm{pH}$ values, depth, waves, currents, sediments, fresh water inputs, pollutants, petroleum platforms and tourist activities differ considerably from anywhere else. All these factors affect the comparison between the species from different geographical areas.

\section{REFERENCES}

Bowker, D. W. (1995): Modeling the patterns of dispersion of length of age in fish Journal of Fisher Biology, 3: 469-484.

Effendie, M. I. (1997): Fisheries biological method. Yayasan Dewi Sri. Bogor. 112 hlm.

Effendie, M. I. (2002): Review of water quality for the management of water resources and environment. Kanisius. Yogyakarta. $258 \mathrm{hlm}$.

El-Ganainy, A. A. and Riad, R. (2008): Population structure of Octopus defilippi (Verany, 1851) from the Gulf of Suez, Red Sea, Egypt. Egy. J. Aquat. Biol. \& Fish., Vol. 12, No. 2: 81-91.

El-Ganainy, A. A.; Yassien, M. H. and Awad, E. I.. Bottom trawl discards in the Gulf of Suez, Red Sea. Egyptian Journal of Aquatic Research, Vol. 31, special issue, 240-255, (2005).

GAFRD (2018): Annual statistical report of the General Authority for fish resources development, Egypt, 118 pp. 
Gaspar, M. B.; Santos, M. N.; Vasconcelos, P. and Monteiro, C. C. (2002): Shell morphometric relationships of the most common bivalve species (Mollusca: Bivalvia) of the Algarve coast (Southern Portugal). Hydrobiologia 477: 73-80.

Gould, S. J. (1966): Allometry and size in ontogeny and phylogeny. Biological Reviews, 41: 587-640.

Jereb, P.; Roper, C. F. E.; Norman, M. D. and Finn, J. K. (2014): Cephalopods of the world. An annotated and illustrated catalogue of cephalopod species known to date. FAO Species Catalogue for Fishery Purposes No. 4, Vol. 3, 352 pp.

Marzuki, M.; Junaidi, M.; Amir, S.; Waspodo, S.; Setyono, B. D. H.; Astriana, B. H.; Nuryadin, R. and Ridwan, M. Weight-Length Relationship and Factors of Octopus Fishery Resources Conditions in the Waters of North Lombok. IOSR Journal of Environmental Science, Toxicology and Food Technology (IOSR-JESTFT). Vol. 12, Issue 10 Ver. II, PP 72-75, (2018).

Norman, M. D. and Hochberg, F. G. (2005): The current state of Octopus taxonomy, Phuket marine biological center research bulletin, 66, pp 127-154.

Osman, I. H.; Gabr, H. R.; El-Etreby, S. G. and Mohammed, S. Z. (2014): Morphometric variations and genetic analysis of Lessepsian migrant Octopus aegina (Cephalopoda: Octopodidae). JKAU: Mar. Sci., Vol. 25. 2, pp: 23-40.

Riad, R. Morphological and taxonomical studies on some cephalopods from the Suez Gulf and Red Sea. Egyptian Journal of Aquatic Research, Vol. 34: 176-201, (2008).

Riad, R. and Gabr, H. R. (2007): Comparative study on Octopus vulgaris (Cuvier, 1797) from the Mediterranean and Red Sea Coasts of Egypt. Egyptian Journal of Aquatic Research, 33(3): 140-146. 
Richter, T. J.: Development and evaluation of standard weight equations forbridgelip sucker and largescale sucker. North American Journal of Fisheries Management, 27: 936-939, (2007).

Ricker, W. E. (1975): Computation and interpretation of biological statistics of fish populations. Bull. Fish. Res. Bd. Can., 191: 1-382.

Rosli, N. A. M. and Isa, M. M. (2012): Length-weight and Length-length relationship of longsnouted catfish, Plicofollisargyropleuron (Valenciennes, 1840) in the Northern Part of Peninsular Malaysia. Journal Tropical Life Sciences Research, 23(2): 59-65.

Sanders, M. J. and Morgan, G. R. (1989): Review of the fisheries resources of the Red Sea and Gulf of Aden. Food \& Agriculture Org. (No. 304).

Sauer, W. H. H.; Gleadall, I. G.; Downey-Breedt, N.; Doubleday, Z.; Gillespie, G.; Haimovici, M.; Ibanez, C. M.; Katugin, O. N.; Leporati, S.; Lipinski, M. R.; Markaida, U.; Ramos, J. E.; Rosa, R.; Villanueva, R.; Arguelles, J.; Briceno, F. A.; Carrasco, S. A.; Che, L. J.; Chen, C.-S.; Cisneros, R.; Conners, E.; Crespi-Abril, A. C.; Kulik, V. V.; Drobyazin, E. N.; Emery, T.; FernandezAlvarez, F. A.; Furuya, H.; Gonzalez, L. W.; Gough, C.; Krishnan, P.; Kumar, B.; Leite, T.; Lu, C.-C.; Mohamed, K. S.; Nabhitabhata, J.; Noro, K.; Petchkamnerd, J.; Putra, D.; Rocliffe, S.; Sajikumar, K. K.; Sakaguchi, H.; Samuel, D.; Sasikumar, G.; Wada, T.; Zheng, X.; Tian, Y.; Pang, Y.; Yamrungrueng, A. and Pecl, G. (2019). World Octopus Fisheries. Journal Reviews in Fisheries Science \& Aquaculture. https://doi.org/10.1080/23308249.2019.1680603

Suruwaky, A. M. and Gunaisah, E. (2013): Identification of Levels of Exploitation of Resources for Male Mackerel (Rastrelliger kanagurta) analysis from the Long Weight Relationship. Aquatic Journal, 4(2): 131-140.

Welcomme, R. L. (2001): Inland Fisheries: Ecology and Management. Blackwell Science Ltd. London. xvii + 353 hal. 
Yedukondala, R. P. and Mohana, R. M. Observations on some aspects of biology of webfoot octopus, Octopus membranaceus Quoy and Gaimard, 1832 off Visakhapatnam, east coast of India. Internationa Journal of Environmental Sciences. Vol. 4, No. 1, ISSN 0976-4402, (2013).

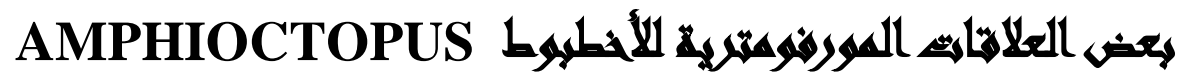 AEGINA (Gray, 1849) السورئ - الهبر الألصر
}

\section{المهتخلس}

اجتذبت الأخطبوطيات (الرأسقدميات) حديثا أهمية علمية فى أماكن مختلفة من العالم حيث

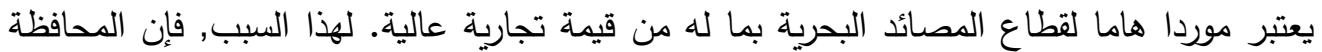

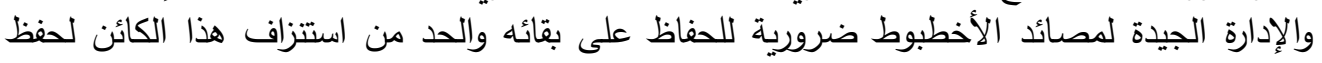

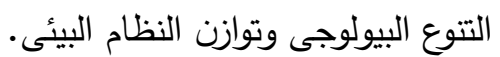

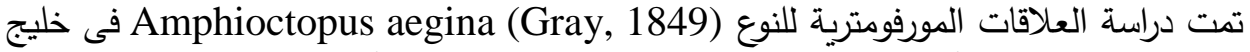

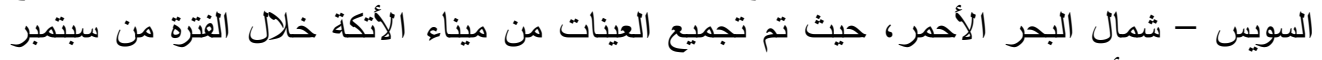

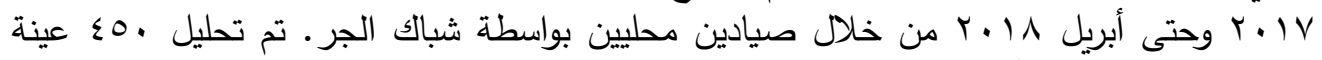

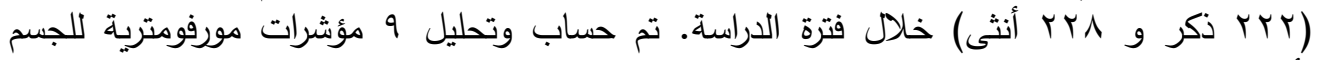

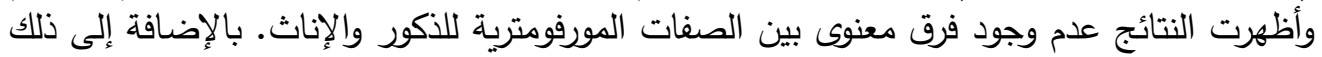

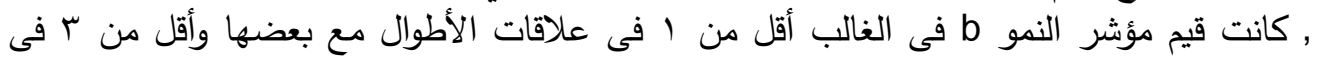

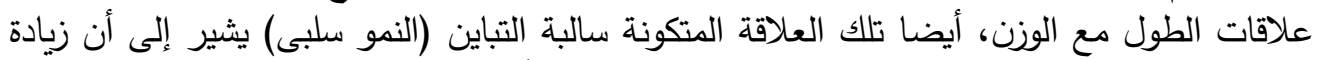

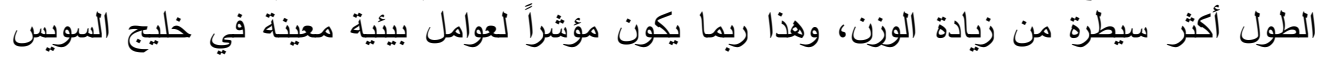


Journal of Environmental Sciences (JES)

Institute of Environmental Studies and Research, Ain Shams University

Ahmed, Ayman. et al.

حيث الظروف البيئية، مثل: درجة حرارة الماء والملوحة وقيم الأس الهيدروجيني واختلاف الأعماق والتيارات البحرية والرواسب ومدخلات المياه العذبة والملوثات والمنصات المات البتات البترولية والأنثطة السياحية.

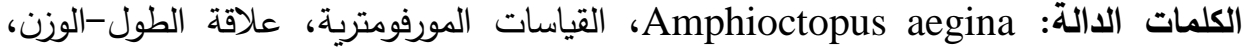
علاقات الطول-الطول، خليج السويس. 